\title{
Public interest oversight on professional accountancy: How do accountants perceive it in Turkey?
}

\author{
Recep Pekdemir ${ }^{\text {a, 1,2 }}$, Nimet Duygu Zigindere ${ }^{\text {b, } 2}$ \\ and Ayca Zeynep Suer b, 2 \\ ${ }^{\text {a }}$ University of Wisconsin La Crosse, USA \\ ${ }^{\mathrm{b}}$ Istanbul University School of Business, Turkey
}

\begin{abstract}
Research Question: The study investigates consequences of the public oversight establishment on accounting profession and also attempts to understand the thoughts and perceptions of the licensed/certified professional accountants on the public oversight activities in Turkey as an emerging country. Motivation: Public oversight activities have been evolved since it has existed less than two decades. After the Sarbanes \& Oxley Act, first initiative was appeared in the United States as the PCAOB Public Company Accounting Oversight Board, then many countries have followed. Public interest oversight institutions play a crucial role as a leader of integrity in ensuring high quality auditing within accurate and informative framework. Idea: This study can be model or benchmark for the studies that can be realized in the other developing countries that might be trying to develop and improve accounting and auditing profession. The study shows the public oversight on accountancy has been a need for a better financial reporting for an effective and efficient financial market. Data: In the survey, members of licensed professional accountants, members of licensed prospective future professional accountants, and licensed auditors were included. Tools: Using a questionnaire, a survey was conducted as a methodological approach to determine the thoughts, perceptions, and expectations of respondents. Findings: The study concludes that professional accountants are aware of public oversight regulations and activities in Turkey. They are mainly thinking that public oversight activities will be impacting

${ }^{1}$ Corresponding author: Department of Accounting, University of Wisconsin La Crosse, USA; email address: rpekdemir@uwlax.edu

${ }^{2}$ We express gratitude to Professor Nadia Albu, Editor-in- Chief, and to anonymous peerreviewer(s) for their valuable comments and support during revision of the paper. We are, however, solely responsible for the paper's errors and omissions.
\end{abstract}


positively to the Turkish public accounting profession. Also, professional accountants mainly perceive that public oversight activities will be contributing efficient and effective financial reporting for financial and money markets in the country. Particularly financial statement audit environment has been changed and up scaled due to inspection activities of the public oversight organization on the auditors and audit firms. The results of the study might be interesting for the stakeholders of the public oversight activities on accounting profession.

Keywords: public oversight, accounting profession, audit, regulations, perceptions

\section{JEL Codes: G18, M4, M49}

\section{Introduction}

The needs for the public oversight on the accounting profession did arise at the beginning of the Millennium due to a series of big accounting scandals such as Enron, WorldCom, Tyco, etc. (McDonough, 2004). The Public Company Accounting Oversight Board (PCAOB) was created as a part of the SarbanesOxley Act in 2002 in the United States (the U.S.) to rebuild public confidence and to protect investors (Harris, 2013). The auditing profession and audit industry of the U.S. had been self-regulated before (Goelzer, 2003) for about a century because of being a common law country. All the stake holders of the subject matter agreed that this approach failed for the public interest since investors could not be protected. This approach had been discussed and compared with the one of the legal-code law countries previously (Baker and Hayes, 1996).

This paper aims to recall the evolution and developments of public interest oversight on professional accountancy and to examine the consequences of the public oversight establishment on accounting profession in Turkey. Also, the paper attempts to understand the thoughts and perceptions of the licensed/certified professional accountants on the public oversight activities in Turkey as an emerging country.

The PCAOB is a not- for-profit corporation chartered by the U.S. Congress, and its mission is "to protect investors and the public interest by promoting informative, accurate, and independent audit reports and to oversee the audits of public companies and broker-dealers." Its vision is "to be a model regulatory organization. Using innovative and cost-effective tools, the PCAOB aims to improve audit quality, reduce the risks of auditing failures in the U.S. public securities market and promote public trust in both the financial reporting process and auditing profession" (PCAOB, 2007). 
The PCAOB has four main responsibilities (Goelzer, 2004a): (1) registering accounting firms that audit the US public companies; (2) inspecting registered accounting firms; (3) establishing auditing, quality control, ethics, independence, other professional standards for accounting firms that audit public companies; and (4) conducting investigations and bringing disciplinary proceedings against registered accounting firms and associated persons possible violations of law or professional standards. In regarding auditing standards setting, at the beginning the PCAOB had adopted interim auditing standards as they existed of generally accepted auditing standards as of April 16, 2003 (Goelzer, 2004b). Then the Board started a long-term project of reviewing all interim standards, and determining if should be modified, repealed, or made permanent, standard by standard (Goelzer, 2004b).

The PCAOB has become a model for both international organizations and countries around the world since its inception (Caramanis et al., 2015). Auditing profession had lost its confidence not only in the US also in many countries around the world. Thus, many countries started to work on how to establish public oversight in order to rebuild public confidence about auditing profession and audit industry. It is because a series of high-profile corporate scandals around the world mentioned above undermined the public confidence in the audit profession credibility. For the public confidence and financial stability, quality of financial information and auditors' opinion were needed for almost more than a hundred years in financial and money markets.

As an outcome of these global initiatives and developments in the accounting and auditing oversight environment, the countries had followed in order to have strong public oversight on accounting and auditing profession whether existing. Turkey as a developing country was one of those. The Public Oversight, Accounting and Auditing Standards Authority (the POAAB) was established in accordance with "Public Oversight, Accounting and Auditing Standards Authority's Organization and Responsibilities Decree Law" numbered 660, issued on November 2, 2011 in Turkey in order to ensure more effective auditing and public oversight system. The POAAB is a governmental, non-for-profit, regulatory body, and the sole supreme authority in determining accounting and auditing standards and ethical rules, authorization, and registration of independent auditors and audit firms under a public oversight system and monitoring their activities within the frame of quality assurance (KGK Booklet, 2018, p 10). The POAAB is an authorized institution that is responsible for achieving an effective public oversight in Turkey. The POAAB is responsible for publishing standards in order to ensure that financial statements and their independent audit comply with international standards (Balsari \& Varan, 2014). In order to establish a high quality and reliable financial reporting and auditing environment, the POAAB has four main functions which are: setting accounting standards, setting auditing standards, authorizing and registering 
auditors and audit firms, overseeing, inspecting and applying legal enforcement to auditors and audit firms (KGK Booklet, 2018, p 10):

- Standard Setting: PAAOB publishes accounting auditing and professional standards to increase trust of investors and other stakeholders in financial statements and independent audit.

- Authorization: It is mandatory for auditors and audit companies to be registered by the PAAOB. Financial statement audit in Turkey, only be carried out by auditors and auditing companies have been registered by the PAAOB.

- Inspection and Investigation: The PAAOB conducts inspections to check the compliance of licensed auditors and registered audit companies with existing laws, regulations and professional standards. Investigations are carried out within the scope of annual review plans and the results are converted into reports and shared with the public. Moreover, when there is a significant audit deficiency, which may cause investors or other stakeholders to make wrong decisions, PAAOB can make investigations outside the plans by using its authority.

- Enforcement: When the PAAOB determines that auditors and audit companies are in violation of existing regulations, they can use sanction or enforce penalties.

In contrasting the $\mathrm{PCAOB}$ and the $\mathrm{POAAB}$, there are certain similarities and differences. The major difference between those is seen in setting standards. The PCAOB has authorities to develop and issue standards related to audit profession and auditing practices, not accounting or financial reporting fields. In addition, the PCAOB has not been licensing certified public accountants who practice in audit and assurance services. The PCAOB register auditing firms, inspect and investigate those, and bring disciplinary proceedings against registered accounting firms and associated persons' possible violations of law or professional standards (Kranacher, 2008). As of December 31, 2018, there were 1,862 audit firms registered by the PCAOB (PCAOB, 2018). Auditing and assurance services shall be carried out only by independent auditors or audit firms, which are authorized by the POAAB in Turkey. Thus, the POAAB has authorities to license independent auditors. Before the POAAB there was no auditor, independent auditor, or audit profession. Auditing and assurance services had been provided by the certified public accountants licensed by the Union of Chambers of Certified Public Accountants of Turkey since 1990. One can argue that licensing the independent auditors in the country was one of the significant changes realized by the POAAB legislation. By the end of 2018, 18,000 professional accountants were licensed by the POAAB as independent auditors since its inception. In regarding practicing, 16,154 of those have been practicing in the market of auditing and assurance services in Turkey by then (KGK Booklet, 2018). 
Turkey as a candidate country to the European Union (EU) membership, seeks to harmonize its legislation with EU legislation. With the establishment of the PAAOB in 2011, the gap between legislation has further narrowed. Accounting, financial reporting and mandatory audit regulations harmonized with EU regulations. Therefore, the PAAOB takes into account EU regulations before making a new regulation. Furthermore, on 25 July 2016 the EU Commission adopted Implementing Decision (EU) 2016/1223 on the equivalence of certain third country public oversight, quality assurance, investigation and penalty systems for auditors and audit firms and a transitional period for audit activities of certain third country auditors and audit firms in the EU. The Decision considers Turkey's audit oversight system as equivalent in relation to audit activities concerning annual or consolidated accounts for financial years starting from 1 August 2016 (KGK Booklet, 2018, p 31).

After summarizing the global changes about public oversight establishment, the study aims to investigate consequences of the public oversight establishment on accounting profession and to make also an attempt to understand the thoughts and perceptions of the licensed/certified professional accountants on the public oversight activities in Turkey as an emerging country. Thus, the study addresses certain questions:

- What differentiations existed in the Turkish public oversight establishment over accounting and auditing environments such as accounting and auditing professions, accounting and auditing standards, and supervision activities on individuals and public accounting companies?

- How activities and accomplishments of the Turkish public oversight establishment are perceived by accounting and auditing professionals of diversity such as different categories of the profession?

\section{Literature review}

Establishing the PCAOB was one of major creation of the Sarbanes - Oxley Act (SOX) in the U.S. As mentioned above one of the keys and core responsibilities of the PCAOB is to inspect audit firms and identify deficiencies in audits of public companies as the government oversight on the auditing profession (PCAOB, 2007).

There have been many studies related to impact of the PCAOB inspections and restrictions on audit quality, investors' expectation, audit partners' perceptions. Since this was the replacement over self-regulation under peer-review of the auditing profession (Lennox and Pittman, 2010), the topic has become an important issue to search in several aspects. 


\subsection{Consequences of public accountancy system on audit quality}

DeFond (2010) argued why studying on the consequences of the PCAOB inspections is important and stated certain reasons. First, the PCAOB inspections can impact auditors' incentives. Second, the PCAOB inspections are a central feature of the shift from the self-regulated to the government oversight. And third, the shift can be interesting because it represents a trade-off between two types of regulations. Riley et al. (2008) stated that the PCAOB standard setting activities and inspection process have had a significant impact on the financial statement auditing process, particularly concerning audit documentation. In $2005-2006$, the PCAOB had imposed some restrictions on auditors' tax services. It was aimed to strengthen auditor independence and improve audit quality as well. It was observed that the restrictions made a significant drop in auditor-provided tax services. Lennox (2016) tested the impact of the restrictions on the audit quality and using a difference - in - differences design, found no change in audit quality for the group relative to the control group after the restrictions were imposed. Gunny and Zhang (2013) examined whether the PCAOB inspections can distinguish actual audit quality (as opposed to perceived) during the period inspected to better understand this important regulatory tool. They asserted that the PCAOB inspections are associated with lower audit quality when the reports are seriously deficient (weaker results for deficient reports). They stated more specifically that clients of triennially inspected auditors that receive a deficient or seriously deficient report are associated with significantly higher abnormal current accruals and clients of auditors that receive a seriously deficient report are associated with a greater propensity to restate.

Among initial activities of the PCAOB, inspections did occur annually for firms (large audit firms) that regularly issue audit reports for more than 100 public companies. Firms (small audit firms) with 100 or fewer issuer clients were subject to inspection no less than once in a three-year period (Riley et al., 2008). Also, Church and Shefchik (2012) analyzed the PCAOB's inspection reports of large, annually inspected firms. They focused on big audit firms in their work, and concluded that audit-related deficiencies followed a decreasing trend between 2004 to 2009. Also, they asserted to identify common, recurring audit deficiencies, determine the financial statement accounts most often impacted by audit deficiencies, and isolate the primary emphasis of financial statement impacted. Similarly, Carcello et al. (2011) examined whether the inspections by PCAOB improved the quality of the audits performed by the big four audit companies. They measured the quality of the audit with the change in client abnormal accruals in the periods following the first two examinations. They found that abnormal accruals decreased significantly in the year following the second PCAOB review. So, they alleged that their results provide evidence that PCAOB reviews improved the quality of the audit. Some researchers have investigated reviews of small audit 
companies conducted by PCAOB. Hermanson et al. (2007) was one of this type of studies. They examined 316 review reports prepared to small audit firms (100 or fewer clients) through July 2006. They stated that sixty percent of the audit companies examined had audit deficiencies. It is found that companies with deficiencies are relatively smaller, less profitable and more highly leveraged.

Krishnan et al. (2017) investigated the impact of PCAOB's first review of foreign audit firms for US cross listed clients. In order to measure the variables, they used the abnormal accruals around the review year and the value relevance of the accounting data around the review report date. It was observed that there was a decrease in abnormal accruals and an increase in the value relevance of the accounting data after the review period compared to the customers who were not examined. They arqued that there are no systematic differences for value relevance or accruals. Similarly, in order to understand the impact of PCAOB's auditor review program, Lamoreaux (2016) examined the relationship between audit quality and PCAOB's access to inspect foreign SEC registered companies. According to the results obtained, it has been determined that the audit companies subject to PCAOB inspection provide a higher quality audit service. As a measure of the audit quality, going concern opinions, reported material weaknesses and earnings management were used. Fung et al. (2017) examined whether PCAOB's international review program has improved the audit quality of companies whose stocks are traded outside the United States. Within the scope of the research, the foreign audits (i.e., non-US auditors) of clients in 55 different countries were examined. Working on a sample of non-US-listed clients of the PCAOB-registered foreign auditors, they asserted that they find the initial PCAOB inspections improve audit quality, over and above the threat of such inspections, for foreign auditors' non-US-listed foreign clients. Also, they stated that the international reviews carried out by $\mathrm{PCAOB}$ were beneficial to the investors of the companies traded outside the USA. DeFond and Lennox (2017) examined whether the reviews by PCAOB improved the quality of internal control systems. They found that as the rate of internal control system deficiencies detected by PCAOB inspectors increased, the auditors provide more adverse opinions about internal control. Also, they stated that auditors provide more adverse internal control opinions to clients with concurrent misstatements, who thus genuinely warrant adverse opinions. Also, they argued that higher inspection deficiency rates have led to higher audit fees, consisted with PCAOB inspections prompting auditors to undertake costly remediation efforts. Lennox and Pittman (2010) analyzed audit firm inspections of the PCAOB in the early years of the legislation. They stated that there is no perception for audit customers that the review reports issued by PCAOB are positive in terms of audit quality. They concluded that less is known about audit firm quality under the regime.

On the other hand, as consequences of the PCAOB's inspections, disciplinary procedures can result penalties that the size of those might be large enough. In one 
of the early years, the PCAOB reported for 2007 that they settled nice disciplinary conducts and resulted about $\$ 1$ million fiscal fine and barring several individuals and firms from practicing public accounting (The PCAOB, 2007). Boone et al. (2015) examined Deloitte's penalty imposed by PCAOB in December 2007 on the company's switching risk, audit fees and audit quality relative to other big auditing firms over the three-year period after the penalty. It was determined that the penalty reduced the company's ability to gain new clients and slowed the rate of increase in audit fees. In addition, the penalty imposed by PCAOB caused the company to bear the actual costs.

\subsection{Consequences of public accountancy system on investors' expectation}

Following the PCAOB inspections reports with identified deficiencies, investors' expectations of the improvement in the credibility of audit opinions also have been studied by researchers. Robertson and Houston (2010) conducted a betweensubject experiment in order to provide evidence concerning investors' perceptions of audit opinion credibility following the PCAOB inspections. They asserted that they found an overall increase in perceptions of the credibility of future audit opinions, the degree to which perceptions increase is a function of three salient characteristics of the $\mathrm{PCAOB}$ reports.

\subsection{Consequences of public accountancy system on audit partners' perceptions}

Houston and Stefaniak (2013) published the results of a study in which the partners of big audit companies participated. They investigated and made a comparison partners perception of the PCAOB inspections and Internal Quality Reviews (IQRs). According to the findings they obtained, it was determined that the partners of the audit company tried to estimate the inspection time. It has been demonstrated that IQR is more useful in understanding whether the auditors' follow the company's audit methodologies, and that IQR examines more of the audit area. In contrast, it has been stated that the reviews by PCAOB aim to find more deficiencies. Partners also believe the IQR feedback is more timely and helpful for improving audit quality.

Both reviews are perceived to impact professional reputation. However, partners perceive the PCAOB inspections increase their firms' litigation risk more so than do IQRs. Finally, less experienced partners perceive reviews as more invasive and as posing more consequences than do more experienced partners.

This study was interesting to understand the perceptions of the supply side of the auditing industry on the PCAOB inspections since it was a big shift created by the SOX. It would be interesting also to understand the perceptions of other stake holders on the PCAOB activities. 


\section{Methodology and research design}

\subsection{Investigating the perceptions of the professional accountants}

Such studies related to the consequences of the public company accounting oversight establishments and recent regulations on the oversight mechanism of auditing in Turkey motivate us to conduct a survey on how professional accountants perceive this change in audit environment through new legislations.

A questionnaire developed and used as a mean to understand and state the perceptions of the professional accountants on the Public Interest Oversight, Accounting and Auditing Standards Board (POAAB) in Turkey. POAAB regulations and activities were examined through the questionnaire.

In this context, such questions were raised:

- Are professional accountants aware of the POAAB regulations and activities?

- What are they thinking of the regulations and activities of the POAAB, pros and cons?

- Do they perceive those regulations and activities are enough or not?

- What do they expect from the POAAB about the future of the audit professional in the country?

- Do they perceive that the POAAB is to contribute to the quality financial statement audit including auditor independence?

\subsection{Methodology}

In order to achieve the aim of the study, a survey was developed and conducted in 2017, in the province of Istanbul that is largest and commercial city in Turkey. Professional accountants practicing and including Sworn in Certified Public Accountants, Certified Public Accountants, and Prospective Future Professional Accountants were respondents. In the early phase of the study, first the regulations and activities of the POAAB were summarized, then research questions, research model, and variables of the research, then a questionnaire were developed. During this phase, thoughts and considerations of the accounting academicians of Istanbul University were taken. In order to understand the professional accountants' perceptions on the POAAB, such statements (See Table 1) were developed:

Besides the statements mentioned, also three open-ended questions were asked for the respondents to express their ideas, thoughts, and recommendations about the $\mathrm{POAAB}$ regulations:

(1) Additional subjects should be investigated and regulated for weakness areas.

(2) Position statement of the current audit profession and practice.

(3) Recommendations to improve more the audit profession and practice. 
Additionally, some demographics of the respondents were needed to test the hypotheses developed. Information such as gender, education, professional title of accountancy, professional title for audit practice, currently practicing, job title at the firm, and pie chart of the portfolio of the clients in the last three years were obtained and used to test the statements and questions mentioned above.

This is a descriptive study understanding and stating the thoughts and perceptions of the professional accountants on the public interest oversight activities in Turkey. Respondents are mainly professional personnel and staff of the audit firms located in Istanbul and its surrounding. Respondents' thoughts and perceptions were tested by nineteen variables through the questions existing in the questionnaire that has three major sections. First having seven questions was for the demographics of the respondents, second having nineteen statements for their thoughts and perceptions, and final was three open ended questions that might be useful for the respondents to express more of their thoughts and perceptions.

The main population of the study would be all professional accountants existing in Turkey. It is not possible to reach out all of those in any manner. Thus, only Istanbul and its surrounding have been chosen to conduct the survey. This might be one of the limitations of the study. On the other hand, Istanbul itself has had a unique place in Turkey in many areas such as number of professional accountants, import \& export figures, national gross income, employment ratio, etc. In the survey, members of licensed professional accountants, members of licensed prospective future professional accountants, and licensed auditors were included. The list of the licensed auditors and the list of the registered audit firms located in Istanbul and its surrounding were taken from the POAAB open sources. Respondents as individuals were categorized as executive partner or head auditor, director, manager, senior auditor, junior auditor, etc. These titles were self-asserted by the respondents so they may vary by the firms.

Totally 143 professional accountants participated to the survey, 13 of those were reached out by the e mail communication, 130 of those were interviewed in person. In both ways a questionnaire was used. Ultimately 139 of those were included to the study to analyze. In the questionnaire, in order to understand the thoughts and perceptions of the respondents, Likert Scale of 5 options was used as 1 - Strongly disagreed, 2 - Disagreed, 3 - Neutral, 4 - Agreed, 5 - Strongly agreed.

For the validity and reliability testing, the value of the Cronbach Alpha was first tested. Generally accepted coefficient (Hair et al., 1998) would be more than $70 \%$ and reliability is increasing when this coefficient is close to $100 \%$. In this study Cronbach Alpha coefficient was measured as $81.2 \%$ so it was accepted as reliable. For the validity assurance, the questionnaire was conducted in different audit firms 
and the faculty members of Istanbul University, then certain adjustments were made.

Information obtained through the questionnaires were first analyzed for the demographics of the respondents. For this purpose, frequency distribution analysis was made. Then for the understanding of thoughts and perceptions of the respondents, frequency distribution analysis was made as well. In order to understand the mean differences between two groups' thoughts and perceptions, independent sample $\mathrm{T}$ - test was used so that the research hypothesis could be tested. And for understanding the mean differences more than two groups, oneway ANOVA was used. These techniques were realized by the Statistical Package for Social Science (SPSS) 17.0.

\section{Presentation of research findings}

\subsection{The respondents' characteristics}

One hundred thirty-nine professional accountants' characteristics are summarized based on gender, education level, professional certification titles, licensure, positions, and practicing in Table 1.

Table 1. Respondents' characteristics

\begin{tabular}{|c|c|c|c|}
\hline & & \multicolumn{2}{|c|}{ Frequency } \\
\hline & & $\mathbf{n}$ & $\%$ \\
\hline \multirow[t]{2}{*}{ Gender } & Female & 22 & 15.8 \\
\hline & Male & 117 & 84.2 \\
\hline \multirow[t]{2}{*}{ Education Level } & Bachelor's degree & 102 & 73.4 \\
\hline & Master's degree & 37 & 26.6 \\
\hline Professional & Certified Public Accountants & 90 & 64.7 \\
\hline Certification & Sworn in Certified Public Accountants & 26 & 18.7 \\
\hline \multirow[t]{2}{*}{ Titles } & Prospective Future Professional Accountants & 9 & 6.5 \\
\hline & Others & 14 & 10.1 \\
\hline \multirow[t]{2}{*}{ Licensure } & Licensed & 107 & 77 \\
\hline & Non-licensed & 32 & 23 \\
\hline \multirow{5}{*}{$\begin{array}{l}\text { Positions at the } \\
\text { Companies They } \\
\text { Work }\end{array}$} & Partners & 44 & 31.7 \\
\hline & Directors & 16 & 11.5 \\
\hline & Managers & 22 & 15.8 \\
\hline & Senior Auditors & 23 & 16.5 \\
\hline & Junior Auditors & 34 & 24.5 \\
\hline \multirow[t]{3}{*}{ Practicing } & Small sized reporting entities & 38 & 27.3 \\
\hline & Medium sized reporting entities & 75 & 54 \\
\hline & Large scale reporting entities & 26 & 18.7 \\
\hline
\end{tabular}

In gender analysis, majority of respondents were male $(84.2 \%)$ and have the bachelor's degree (73.4\%). Of the respondents 64.7 percent are certified public 
accountants. In regarding licensed auditor certificate analysis, $77 \%$ of the respondents were licensed. On the other hand, $46 \%$ of the respondents have been practicing in financial statement audit environment, 54\% of those not. It means that some of the licensed auditors have not been in the audit market even though they have license. In regarding practicing, 27.3\% of the respondents engaged with financial statement audit for small sized reporting entities, 54\% of those engaged for medium sized, and $18.7 \%$ of those engaged in large scale reporting entities.

\subsection{Empirical findings}

Our survey-based study addresses the research questions raised for understanding the consequences of the establishment of an oversight system in Turkey. T-test and ANOVA test were conducted to understand whether significant differences existing among the respondents' thoughts and perceptions by their demographics on the provided statements related to the POAAB and its activities. Independent samples $\mathrm{t}$ - test was conducted since two different samples as population were compared and one-way ANOVA test was used since more than two samples were included. Table 2 presents the empirical findings of our study.

Table 2. Empirical findings

\begin{tabular}{|c|c|c|c|}
\hline \multirow[b]{2}{*}{ Statements } & \multirow[b]{2}{*}{ Sig. (2-tailed) } & \multicolumn{2}{|c|}{ Mean } \\
\hline & & $\begin{array}{l}\text { Certified } \\
\text { Public } \\
\text { Accountant } \\
(\mathrm{n}=90)\end{array}$ & $\begin{array}{l}\text { Sworn in } \\
\text { Certified Public } \\
\text { Accountant } \\
(\mathrm{n}=26)\end{array}$ \\
\hline $\begin{array}{l}\text { POAAB has had personnel qualified enough to } \\
\text { inspect audit firms }\end{array}$ & 0.269 & 3.1111 & 2.8846 \\
\hline $\begin{array}{l}\text { POAAB regulations against impairments of the } \\
\text { independence matter are good enough }\end{array}$ & 0.243 & 3.1111 & 2.8462 \\
\hline \multirow[t]{3}{*}{$\begin{array}{l}\text { Sanctions and penalties conducted by the POAAB } \\
\text { have been preventive }\end{array}$} & 0.184 & 3.5556 & 3.1923 \\
\hline & & \multicolumn{2}{|c|}{ Mean } \\
\hline & Sig. (2-tailed) & $\begin{array}{l}\text { Having } \\
\text { bachelor's } \\
\text { degree } \\
(\mathrm{n}=102)\end{array}$ & $\begin{array}{l}\text { Having Master's } \\
\text { Degree }(n=37)\end{array}$ \\
\hline $\begin{array}{l}\text { POAAB's mandatory continues development } \\
\text { programs for the auditors has improved the auditors' } \\
\text { knowledge }\end{array}$ & 0.091 & 3.8725 & 3.5135 \\
\hline POAAB increased the auditor's respectfulness & 0.269 & 3.5784 & 3.7838 \\
\hline $\begin{array}{l}\text { Conventions organized by the POAAB have been } \\
\text { effective and efficient for audit profession }\end{array}$ & 0.325 & 3.7353 & 3.8919 \\
\hline
\end{tabular}




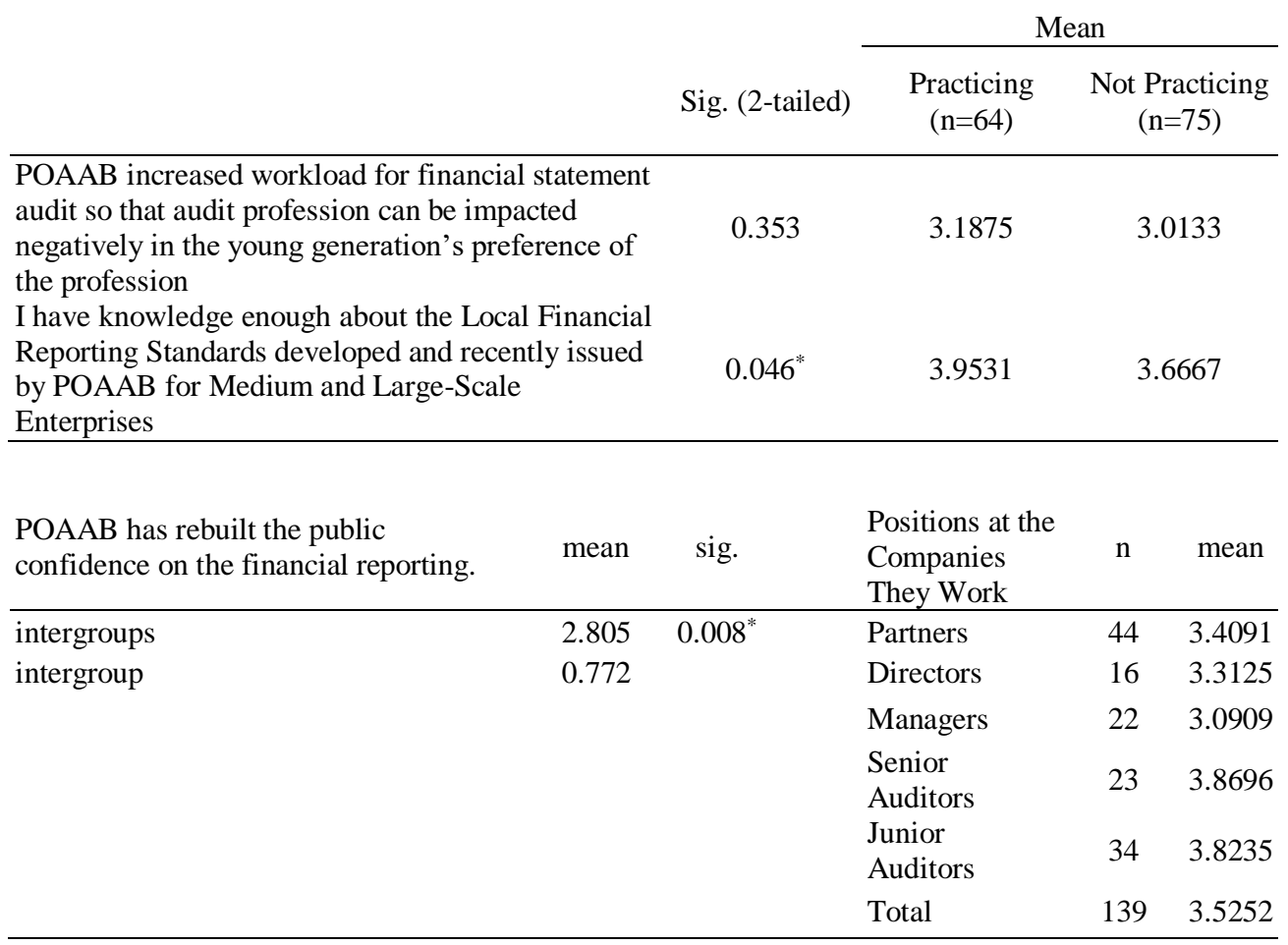

There has been significant difference among the respondents' thoughts and perceptions by their positions whether they are in the audit practices on the statement of "I have knowledge enough about the Local Financial Reporting Standards developed and recently issued for Medium and Large-Scale Enterprises." (Statement No 15) (the independent samples t-test in 95\% confidence interval and 0.046 significance level, Table 2).

There has been significant difference among the respondents' thoughts and perceptions by their positions at the companies they work on the statement of "POAAB has rebuilt the public confidence on the financial reporting." (Statement No 3) (the one-way ANOVA test in 95\% confidence interval and 0.008 significance level, Table 2). On the other hand, it is observed that there has been a significant incremental increase on the thoughts and perceptions from manager to partners in the respondents' positions at the companies they work. Junior and senior auditors' thoughts and perceptions on this statement are higher than even partners' perceptions (Table 2). Table 3 reports the descriptive statistics of the thoughts and perceptions of the respondents. 
Table 3. Descriptive statistics of the thoughts and perceptions of the respondents

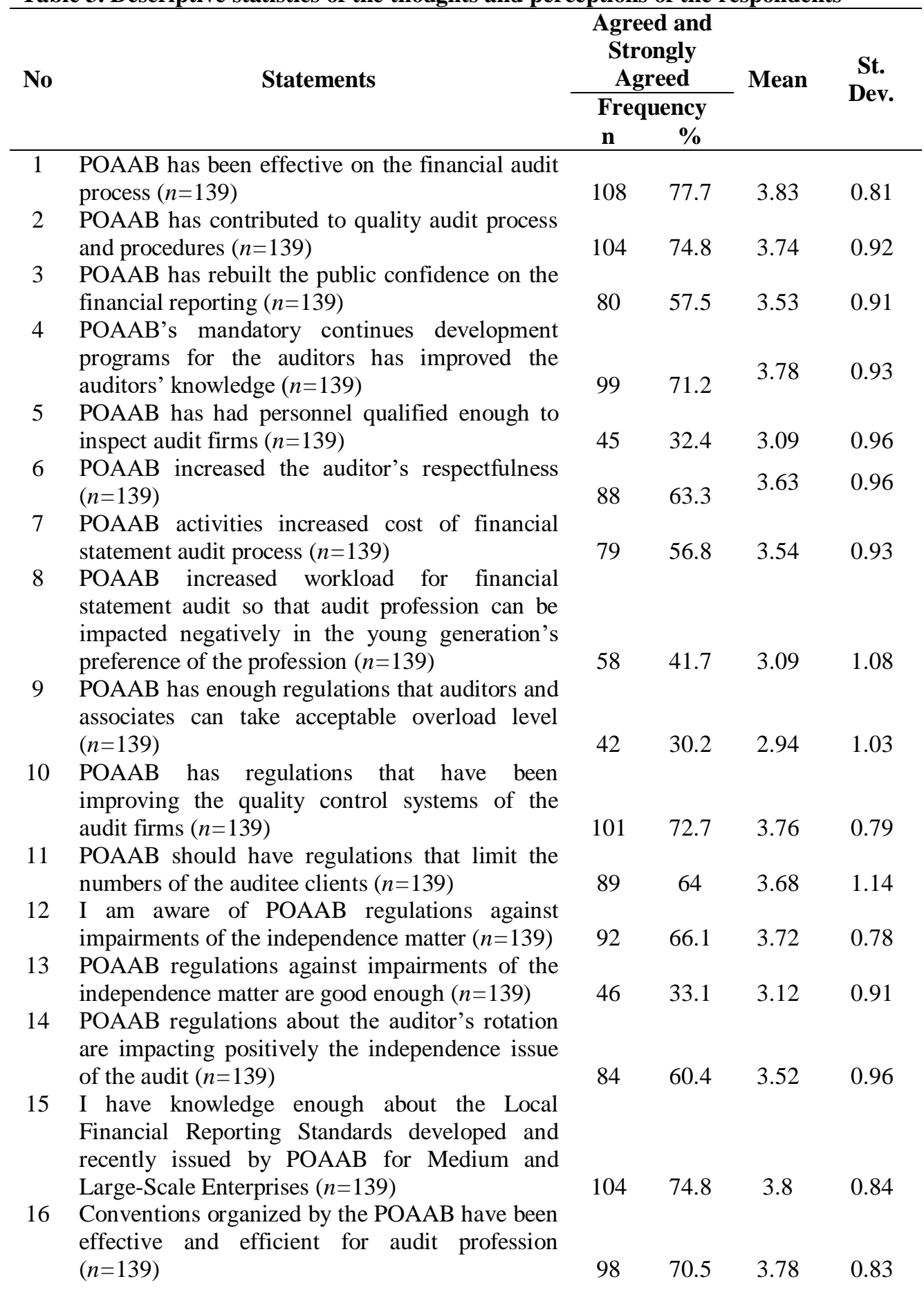




\begin{tabular}{|c|c|c|c|c|c|}
\hline \multirow[t]{3}{*}{ No } & \multirow[t]{3}{*}{ Statements } & $\begin{array}{r}\mathbf{A g} \\
\mathbf{S} \\
\mathrm{A}\end{array}$ & $\begin{array}{l}1 \text { and } \\
\text { igly } \\
\text { eed }\end{array}$ & \multirow[t]{3}{*}{ Mean } & \multirow{3}{*}{$\begin{array}{c}\text { St. } \\
\text { Dev. }\end{array}$} \\
\hline & & \multicolumn{2}{|c|}{ Frequency } & & \\
\hline & & $\mathbf{n}$ & $\%$ & & \\
\hline 17 & $\begin{array}{l}\text { Number of conventions organized by POAAB } \\
\text { has been enough }(n=139)\end{array}$ & 45 & 32.4 & 3.01 & 0.94 \\
\hline 18 & $\begin{array}{l}\text { I think POAAB regulations about the continues } \\
\text { development program has been a must }(n=139)\end{array}$ & 93 & 66.9 & 3.69 & 0.97 \\
\hline 19 & $\begin{array}{l}\text { Sanctions and penalties conducted by the } \\
\text { POAAB have been preventive }(n=139)\end{array}$ & 81 & 58.3 & 3.53 & 1.02 \\
\hline
\end{tabular}

When we analyze the responses of the participants collectively, we can argue that PAAOB is effective on independent audit practices, contributes to the quality of audit in the country, increases public trust in financial reporting, and increases independence in independent audit. In addition, strong answers have not been obtained that PAAOB has sufficient competent personnel to examine audit firms and that it has made arrangements to ensure that auditors and their assistants have a reasonable workload.

\section{Conclusions}

\subsection{Contribution}

The study can have possible contributions not only for Turkish accounting and auditing environment, but also the outcomes can be model for some developing countries that are at the primitive phase of the public interest oversight legislation or have nothing so far.

It is expected that the outcomes of the research study can contribute to the further developments that might be needed to make some amendments in the regulation in Turkey since just five years past from the beginning of the POAAB activities. Also, professional accountancy bodies in Turkey can benefit for their members.

This study can be model or benchmark for the studies that can be realized in the other developing countries that might be trying to develop and improve accounting and auditing profession. It seems no doubt government regulation over public company accounting and auditing has been bearing such benefits for building public trust in financial reporting environment and increasing not only audit quality but also earnings management quality. 


\subsection{Conclusions and recommendations}

This paper aims to examine the developments of the public oversight activities over accounting profession since these activities were recently initiated. One can argue that the oldest one has been the U.S. Public Company Accounting Oversight Board established in 2003. Aftermaths both global organizations and many countries developed or developing have followed the U.S. being one of those, Turkey launched the POAAB in 2013 ten years behind the U.S.

One of the major stakeholders of the public oversight activities over accounting profession has been professional accountants that no matters they are called such as certified public accountants, chartered accountants, independent auditors, expert comptables, etc. There is no doubt that public oversight activities over accounting profession, particularly inspections conducted public accounting firms have taken more attentions for accounting researchers. This study also attempted to state the position of the public oversight organization through understanding and determining thoughts and expectations of professional accountants in Turkey. The study concludes that professional accountants are aware of public oversight regulations and activities in Turkey. They are mainly thinking that public oversight activities will be impacting positively to the Turkish public accounting profession. Also, professional accountants mainly perceive that public oversight activities will be contributing efficient and effective financial reporting for financial and money markets in the country. Our findings are useful to regulators in determining the oversight mechanism of auditors.

This study has also some limitations and weaknesses that only limited number of professional accountants were admitted to reach the purpose of the study. Also, research methodology might be arguable to conclude about thoughts and expectations of professional accountants currently. However, this can be a good start to further or replica studies at the matter in near or far future for such developing countries.

\section{References}

Baker, C. R. \& Hayes, R. S. (1996) "Regulating the public accounting profession: an international perspective", http://panopticon.csustan.edu/ cpa96/pdf/baker2.pdf Accessed on 10/14/2019

Balsari, C.K. \& Varan, S. (2014) "IFRS implementations and studies in Turkey", Accounting and Management Information Systems, vol. 13, no. 2: 373-399

Boone, J.P, Khurana, I.K. \& Raman, K.K. (2015) "Did the 2007 PCAOB disciplinary order against Deloitte impose actual costs on the firm or improve its audit quality?", The Accounting Review, vol. 90, no. 2: 405441 
Caramanis, C., Dedoulis, E. \& Leventis, S. (2015) "Transplanting Anglo-American accounting oversight boards to a diverse institutional context," Accounting, Organizations and Society, no 42:12-31

Carcello, J.V., Hollingsworth, C. \& Mastrolia, S.A. (2011) "The effect of PCAOB inspections on Big 4 audit quality", Research in Accounting Regulation, no 23: 85-96

Church, B.K. \& Shefchik, L.B. (2012) "PCAOB inspections and large accounting firms," Accounting Horizons, vol. 26, no. 1:43-63

DeFond, M. (2010) "How should the auditors be audited? Comparing PCAOB inspections with the AICPA peer reviews", Journal of Accounting and Economics, vol. 49:104-108

DeFond, M.L. \& Lennox, C.S. (2017) "Do PCAOB inspections improve the quality of internal control audits?" Journal of Accounting Research, vol. 55, no. 3: 591-627

Fung, S.Y.K, Raman, K.K. \& Zhu, X.K. (2017) "Does the PCAOB international inspection program improve audit quality for non-us-listed foreign clients?" Journal of Accounting and Economics, no. 6: 15-36

Goelzer, D.L. (2003) "Restoring public confidence", Retrieved from https://pcaobus.org/News/Speech/Pages/09152003_GoelzerRestoringPubli

cConfidence.aspx Accessed on 10/10/2019

Goelzer, D.L. (2004a) "The PCAOB and Public Companies", (February 25) Retrieved from

https://pcaobus.org/News/Speech/Pages/02252004_GoelzerPCAOBAndPublicCom panies.aspx, Accessed on 10/14/2019

Goelzer, D.L. (2004b) "The First 500 Days", (May 18) Retrieved from

https://pcaobus.org/News/Speech/Pages/05182004_GoelzerFirst500Days.aspx, Accessed on 10/12/2019

Goelzer, D.L. (2005) "PCAOB Update: A Year-Three Progress Report and 2006 Challenges", Retrieved from https://pcaobus.org/News/Speech/Pages/ 12152005_GoelzerColoradoSocietyofCPAs.aspx

Accessed on 10/12/2019

Gunny, K.A. \& Zhang, T.C. (2013) "PCAOB inspection reports and audit quality" Journal of Accounting and Public Policy, vol. 32, issue 2:136-160

Hair, J. F., Anderson, R. E. Tatham, R. L. \& Black, W. C. (1998) Multivariate Data Analysis, $5^{\text {th }}$ edition, London: Prentice Hall Int.

Harris, S.B. (2013) "Background on the PCAOB", Retrieved from https://pcaobus. org/News/Speech/Pages/05162013_Kennesaw.aspx, Accessed on $10 / 8 / 2019$.

Hermanson, D.R., Houston, R.W. \& Rice, J.C. (2007), "PCAOB inspections of smaller cpa firms: initial evidence from inspection reports," Accounting Horizon, vol. 21, no. 2:137-152

Houston, R. W. \& Stefaniak, C.M. (2013) “Audit partner perceptions of post-audit review mechanisms: an examination of internal quality reviews and 
PCAOB inspections," Accounting Horizons, vol. 27, no 1:23-49, https://ifac.org Accessed on 10/9/2019

KGK Booklet - January 2018.pdf, https://www.kgk.gov.tr, Accessed on $10 / 20 / 2019$

Kranacher, M.J. (2008) “The PCAOB's primary mission: improving confidence in financial reporting", The CPA Journal, Jan 2008, 78, 1.

Krishnan, J., Krishnan, J. \& Song, H. (2017) "PCAOB international inspections and audit quality," The Accounting Review, vol. 92, no. 5:143-166

Lamoreaux, P.L. (2016) "Does PCAOB inspection access improve audit quality? An examination of foreign firms listed in the United States," Journal of Accounting and Economics, no. 61: 313-337

Lennox, C. S. (2016) 'Did the PCAOB's restrictions on auditors' tax services improve audit quality?" The Accounting Review, vol. 91, no 5:1493-1512

Lennox, C.S. \& Pittman, J. (2010) "Auditing the auditors: Evidence on the recent reforms to the external monitoring of audit firms, "Journal of Accounting and Economics, vol. 49:84-103

McDonough, W.J. (2004) "The PCAOB and its oversight role", Retrieved from https://pcaobus.org/News/Speech/Pages/03092004_McDonoughJointFinan

cialManagement.aspx, Accessed on 10/12/2019

PCAOB (2007) Public Company Accounting Oversight Board, Report on the PCAOB's 2004, 2005, and 2006 Inspections of Domestic Triennially Inspected Firms, PCAOB Washington, D.C.

PCAOB (2018) 2018 Annual Report Public Company Accounting Oversight Board, Washington, D.C.

Riley, R.R., Jr, Jenkins, J.G., Roush, P.Y. \& Thibodeau, J.C. (2008) "Audit quality in the post-SOX audit environment: what your auditing students must know about the PCAOB inspection process," Current Issues in Auditing, vol. 2, issue 2: A17-A25

Robertson, J.C. \& Houston, R.W. (2010) "Investors' expectations of the improvement in the credibility of audit opinions following PCAOB inspection reports with identified deficiencies," Accounting and the Public Interest, vol. 10: 36-56 